І. Г. Капелька ${ }^{1}$, С. Ю. Штриголь ${ }^{1}$, Р. Б. Лесик ${ }^{2}$, А. В. Лозинський ${ }^{2}$, С. В. Хом'як ${ }^{3}$, В. П. Новіков ${ }^{3}$

\title{
Скринінг низки інгібіторів каскаду арахідонової кислоти на фригопротекторні властивості
}

\author{
${ }^{1}$ Національний фармацевтичний університет, м. Харків \\ 2 Львівський національний медичний університет імені Данила Галицького \\ ${ }^{3}$ Національний університет «Львівська Політехніка», м. Львів
}

Ключові слова: холодова травма, фригопротекторна дія, нестероїдні протизапальні препарати, каскад арахідонової кислоти

Холодові травми (ХT), у тому числі відмороження та загальне охолодження, донедавна були в основному проблемою військових. Однак сьогодні зростає частота холодових уражень серед цивільного населення. Це пов'язано зі зростаючою популярністю активного способу життя та таких його елементів, як спортивний туризм, катання на лижах і ковзанах, альпінізм. Також зростає число безхатченків, що входять до групи ризику [1].

ХT завдають значних збитків системі охорони здоров'я. В Україні щорічно реєструється понад 12000 випадків ХТ. Переважно це особи працездатного віку, що потребують стаціонарного лікування, а смертність складає $10 \%$. ХТ можуть призвести до значних ускладнень, а їхнє лікування триває в середньому в два рази довше за лікування опіків. Спектр ускладнень варіює від незначної втрати тканин 3 помірною тривалістю відновлення до масивного некротичного ураження, що призводить до ампутації та подальших фантомних болей $[1,2]$.

Існує низка факторів ризику щодо ймовірності отримання XT, а саме: вживання алкоголю та наркотичних речовин, психічні захворювання, технічні несправності (наприклад, поломка транспортного засобу під час несприятливих погодних умов). До модифікуючих факторів, що погіршують прогноз лікування, належать серцево-судинні захворювання з порушенням мікроциркуляції.

(c) Колектив авторів, 2020
Патологічний процес, що розвивається за ХT, можна умовно поділити на 4 фази: передзаморожування, замерзання-відтаювання, судинний застій i прогресуюча або пізня ішемічна фаза. За спрощеного підходу виділяють 2 фази: фаза переохолодження-замерзання та фаза судинних реакцій [1].

Шкірна чутливість втрачається за охолодження до $+10{ }^{\circ} \mathrm{C} .3$ подальшим зниженням температури збільшується в'язкість судинного вмісту, звужується просвіт судин і спостерігається трансендотеліальний витік плазми. За подальшого охолодження шкіри до $0{ }^{\circ} \mathrm{C}$ відбувається замерзання та утворення кристалів льоду, що зумовлюють пошкодження навколишніх тканин. За охолодження шкіри індукована холодом вазоконстрикція чергується 3 вазодилатацією, розвивається судинна реакція Льюїса з почерговими циклами по 5-10 хв, що закінчується стійкою вазоконстрикцією та централізацією кровообігу для зменшення втрат тепла. Залежно від методу відігрівання розвивається гіперемія, ішемія, ціаноз або загальна недостатність кровообігу. За вазодилатацією та едемою з'являються заповнені ексудатом пухирці, розвивається реперфузійне пошкодження [1-3].

Значну роль у розвитку ХT відіграють продукти метаболізму арахідонової кислоти. Простагландин $\mathrm{F}_{2 \alpha}\left(\mathrm{PGF}_{2 \alpha}\right)$ i тромбоксан $\mathrm{A}_{2}\left(\mathrm{TXA}_{2}\right)$ викликають агрегацію тромбоцитів і тромбоз, що призводить до ішемізації тканини, а також беруть участь у розвитку запальної реакції. Крім того, збільшується утворення простацикліну $\left(\mathrm{PGI}_{2}\right)$, який $€$ функціональним антагоністом $\mathrm{PGF}_{2 \alpha}$ та 
TXA $_{2}$ і дещо сповільнюе розвиток ішеміï. 3 урахуванням механізму розвитку $\mathrm{XT}$ можна вважати перспективними фригопротекторами нестероїдні протизапальні препарати (НПЗП), які пригнічують синтез простагландинів $[4,5]$.

Фригопротекторні властивості доведено для ацетилсаліцилової кислоти (АСК), мелоксикаму та целекоксибу [2, $6,7,9-12]$. Нами виявлено таку активність у диклофенаку натрію [2]. Однак потребує уточнення залежність виразності фригопротекторного впливу від селективності НПЗП щодо ЦОГ-2. Привертає увагу також інноваційний препарат дарбуфелон - подвійний інгібітор ЦОГ-2/5-ЛОГ, який розробляється як протизапальний і протипухлинний засіб $[8,9]$. 3'ясування його фригопротекторних властивостей важливе 3 огляду на можливу участь продуктів ліпоксигеназної реакції - лейкотрієнів - у патогенезі ХT. Насамкінець, доцільно з'ясувати вплив на ХT інгібіторів ЦОГ-3 - аналгетиків-антипіретиків, які не мають виразних протизапальних властивостей.

Мета дослідження - порівняти виразність фригопротекторного ефекту низки НПЗП з різною селективністю й аналгетика-антипіретика парацетамолу на моделі гострого загального охолодження (ГЗО) у мишей.

Матеріали та методи. Дослідження виконано на базі Навчально-наукового тренінгового центру медико-біологічних досліджень Навчально-наукового інституту прикладної фармації на білих мишах самцях масою 20-24 г (78 особин) протягом одного дня 312.00 до 18.00 год.

Тварин утримували на стандартному харчовому раціоні віварію за вільного доступу до води, постійної вологості та температурного режиму $+22-23{ }^{\circ} \mathrm{C}$. Під час виконання експерименту дотримано норми та принципи, затверджені Гельсінською декларацією щодо гуманного поводження 3 тваринами (2000р.) та Директивою Ради Європейського Союзу щодо захисту тварин, які використовуються з наукової метою (2010р.).

Для моделювання ГЗО мишей вміщували до індивідуальних пластикових кліток об'ємом $500 \mathrm{~cm}^{3}$ без обмеження рухової активності та доступу повітря, розташовували в морозильній камері «Nord Inter-300» 3 прозорою кришкою за температури $-18{ }^{\circ} \mathrm{C}$. Інтегральним показником фригопротекторної дії обрано час життя тварин [10].

у дослідженні використовували наступні препарати та субстанції: неселективні інгібітори ЦОГ - АСК (Аспірин, таблетки, «Bayer», Німеччина), диклофенак натрію (Вольтарен, таблетки, «Novartis», Швейцарія); високоселективні інгібітори ЦОГ-2 -целекоксиб (Целебрекс, таблетки, «Pfizer», США), еторикоксиб (Аркоксія, таблетки, «Merck Sharp \& Dohme Idea Inc», США); подвійні інгібітори ЦОГ-2/5ЛОГ - дарбуфелон, дарбуфелону мезилат, 5-(3,5-ди-трет-бутил-4-гідроксибензиліден)-2-(тіазол-2-іліміно)-тіазолідин-4-он; інгібітор ЦОГ-3 - парацетамол (Панадол, таблетки, «Glaxo Smith Kline plc», Ірландія). Дарбуфелон, його сіль(метансульфонат) та 5-(3,5-ди-третбутил-4-гідроксибензиліден)-2-(тіазол2-іліміно)-тіазолідин-4-он (рисунок) синтезовано на кафедрі фармацевтичної, органічної та біоорганічної хімії Львівського національного медичного університету імені Данила Галицького під керівництвом професора Р. Б. Лесика.

Таблетки/порошок подрібнювали в ступці та суспендували у воді з додаванням твіну-80. Суспензії вводили крізь зонд внутрішньошлунково в<smiles>CC(C)(C)c1cc(/C=C2\SC(N)=NC2=O)cc(C(C)(C)C)c1O</smiles>

Рисунок. Хімічна структура дарбуфелону (А), дарбуфелону метансульфонату (мезилату) (В) і 5-(3,5-ди-трет-бутил-4-гідроксибензиліден)-2-(тіазол-2-іліліно)-тіазолідин-4-ону (C) 
об’ємі 10 мл/кг маси тіла (по 0,200,24 мл на тварину) у профілактичному режимі за 30 хв до XT, як рекомендується в дослідженні фригопротекторних властивостей [8]. Тварин випадковим чином розділили на 13 груп: 1 група - контрольна патологія (XT), $\mathrm{n}=6$ (вводили воду, 10 мг/кг); 2 група $\mathrm{ACK}, 50 \mathrm{мг/кг} \mathrm{+} \mathrm{XT}(\mathrm{n}=6) ; 3$ група парацетамол, 125 мг/кг + XT $(\mathrm{n}=6)$; 4 група - парацетамол, 250 мг/кг + XT $(\mathrm{n}=6) ; 5$ група - дарбуфелон, 30 мг/кг + $\mathrm{XT}(\mathrm{n}=6) ; 6$ група - дарбуфелону мезилат, 20 мг/кг + XT (n =6); 7 група дарбуфелону мезилат, 40 мг/кг + XT $(\mathrm{n}=6) ; 8$ група - дарбуфелону мезилат, 100 мг/кг + XT (n = 6); 9 група 5-(3,5-ди-трет-бутил-4-гідроксибензиліден)-2-(тіазол-2-іліміно)-тіазолідин-4он, 40 мг/кг + XT $(\mathrm{n}=6) ; 10$ група диклофенак натрію, 14 мг/кг + XT (n = 6); 11 група - целекоксиб, 74 мг/кг + $\mathrm{XT}(\mathrm{n}=6) ; 12$ група - еторикоксиб, 10 мг/кг + XT (n =6); 13 група - еторикоксиб, 20 мг/кг + ХT (n=6). АСК, диклофенак натрію та целекоксиб використали як препарати порівняння з доведеною фригопротекторною активністю.

Дози препаратів обрано на підставі даних літератури та попередніх досліджень. АСК вводили в дозі 50 мг/кг [14]. Диклофенак і целекоксиб використовували в дозах 14 мг/кг і 74 мг/ кг відповідно [2, 11-14]. Дарбуфелону мезилат в експерименті застосовують у дозах 10-180 мг/кг [15-17], тому використано 3 дози: 20, 40 і 100 мг/кг. 3 огляду на цей діапазон обрано дози дарбуфелону та 5-(3,5-ди-трет-бутил-4гідроксибензиліден)-2-(тіазол-2-іліміно)-тіазолідин-4-ону (відповідно 30 мг/ кг і 40 мг/кг). Дози інших препаратів розраховували виходячи 3 середніх терапевтичних доз людини з використанням рекомендованих FDA коефіцієнтів перерахунку [18].

Для статистичної обробки використовували критерій Краскела-Уолліса для множинного порівняння та U-критерій Манна-Вітні для попарного порівняння. Аналіз проводили за допомогою програми Statistica 13.5. Результати наведено у вигляді $\mathrm{M} \pm \mathrm{m}$ та $\mathrm{Me}\left[\mathrm{Q}_{1}\right.$; $\mathrm{Q}_{3}$ ]. Відмінності вважали статистично значущими в разі $\mathrm{p}<0,05$ (з урахуванням перерахунку на кількість досліджуваних груп) [19].

Результати та їх обговорення. Результати дослідження наведено в таблиці.

Як можна бачити з даних таблиці, парацетамол у широкому діапазоні доз не спричинив достовірного збільшення часу життя тварин за умов XT - ефект спостерігався на рівні слабкої тенденції. Це може означати, що ЦОГ-3, яку парацетамол інгібує в головному мозку, відіграє незначну роль у розвитку ХT.

Інші препарати розташувалися за збільшенням фригопротекторного впливу таким чином: АСК, 50 мг/кг = дарбуфелон, 30 мг/кг < диклофенак, 14 мг/кг < целекоксиб, 74 мг/кг < еторикоксиб, 20 мг/кг < 5-(3,5-ди-третбутил-4-гідроксибензиліден)-2-(тіазол2-іліміно)-тіазолідин-4-он, 40 мг/кг < еторикоксиб, 10 мг/кг < дарбуфелону мезилат, 20 мг/кг < дарбуфелону мезилат, 100 мг/кг < дарбуфелону мезилат, 40 мг/кг. Щодо АСК, то цей НПЗП у дозі 50 мг/кг спричинив достовірний, хоча й помірний фригопротекторний ефект (таблиця). У нашому попередньому дослідженні АСК у меншій дозі 25 мг/кг лише тенденційно збільшувала тривалість життя тварин [2] за умов ХT у середньому на $14 \%$. Вочевидь, АСК притаманна дозозалежність фригопротекторної дії. Серед НПЗП найкращий ефект демонструє еторикоксиб у дозі 10 мг/кг. Це можна частково пояснити тим, що саме індуцибельна ЦОГ-2 більшою мірою відповідає за утворення $\mathrm{PGI}_{2}$, який викликає розширення судин [20]. Можна припустити, що блокування ЦОГ-2 запобігає розширенню судин, викликаному $\mathrm{PGI}_{2}$, що сприяє централізації кровообігу та збереженню тепла. За ефективністю еторикоксиб дещо перевершує лідера попереднього скринінгу [2] целекоксиб i, на відміну від нього, у відносно низькій дозі 10 мг/кг демонструє достовірно кращий ефект, ніж АСК (таблиця).

Найвищий фригопротекторний ефект серед досліджених інгібіторів каскаду арахідонової кислоти чинить дарбуфелону мезилат у широкому діапазоні доз. У дозі 40 мг/кг його ефект макси- 
тривалість життя мишей із гострою холодовою травлою за впливу низки інгібіторів каскаду арахідонової кислоти $(n=6)$

\begin{tabular}{|c|c|c|c|c|c|}
\hline \multirow[t]{2}{*}{ Група, препарат } & \multirow{2}{*}{$\begin{array}{l}\text { Доза, } \\
\text { мг/кг }\end{array}$} & \multicolumn{2}{|c|}{ Час життя, хв } & \multicolumn{2}{|c|}{$\begin{array}{r}\text { Відмінність } 3 \\
\text { контролем, \% }\end{array}$} \\
\hline & & $\mathbf{M} \pm \mathbf{m}$ & $\operatorname{Me}\left[Q_{1} ; Q_{3}\right]$ & M & Me \\
\hline Контрольна патологія & - & $44,8 \pm 2,5$ & $42[40 ; 52]$ & - & - \\
\hline $\begin{array}{l}\text { Ацетилсаліцилова } \\
\text { кислота }\end{array}$ & 50 & $52,1 \pm 1,6^{\star}$ & $53[49 ; 57]^{\star}$ & $+16,3$ & $+26,2$ \\
\hline \multirow{2}{*}{ Парацетамол } & 125 & $50,2 \pm 2,8$ & $53,5[44 ; 55]$ & $+12,1$ & $+27,4$ \\
\hline & 250 & $49,2 \pm 2,0$ & $49[45 ; 50]$ & $+9,8$ & $+16,7$ \\
\hline Дарбуфелон & 30 & $51,8 \pm 1,6^{\star *}$ & $53[48 ; 55]^{\star \star}$ & $+15,6$ & $+26,2$ \\
\hline \multirow{3}{*}{$\begin{array}{l}\text { Дарбуфелону } \\
\text { мезилат }\end{array}$} & 20 & $63,7 \pm 4,3^{\star \star,} \&$ & $61,5[57 ; 76]^{\star \star, \&}$ & $+42,2$ & $+46,4$ \\
\hline & 40 & $70,0 \pm 3,1^{\star \star,}, \&, \S$ & $69,5[64 ; 78]^{\star \star, ~ \&, \S}$ & $+56,3$ & $+65,5$ \\
\hline & 100 & $65,9 \pm 1,3^{\star *, \&, \S}$ & $66[63 ; 68]^{\star *, \&, \S}$ & $+47,1$ & $+57,1$ \\
\hline $\begin{array}{l}\text { 5-(3,5-ди-трет-бутил- } \\
\text { 4-гідроксибензилі- } \\
\text { ден)-2-(тіазол-2-ілі- } \\
\text { міно)-тіазолідин-4-он }\end{array}$ & 40 & $59,3 \pm 3,5^{\star *}$ & $56,5[54 ; 60]^{\star \star}$ & $+32,4$ & $+34,5$ \\
\hline Диклофенак натрію & 14 & $58,6 \pm 4,8^{*}$ & $54[51 ; 68]^{\star}$ & $+30,8$ & $+28,6$ \\
\hline Целекоксиб & 74 & $57,1 \pm 3,3^{*}$ & $55[51 ; 63]^{\star}$ & $+27,5$ & $+30,1$ \\
\hline \multirow{2}{*}{ Еторикоксиб } & 10 & $57,5 \pm 0,3^{\star \star,} \&$ & $58[57 ; 58]^{\star \star, \&}$ & $+28,3$ & $+38,1$ \\
\hline & 20 & $53,2 \pm 2,7^{\star}$ & $55,5[46 ; 57]^{\star}$ & $+18,8$ & $+32,1$ \\
\hline
\end{tabular}

Примітка. Статистично значущі відмінності: *3 контрольною патологією $(p<0,05)$, **з контрольною патологією $(p<0,01),{ }^{\star} 3$ показником групи $A C K(p<0,05), \S_{3}$ показникол групи еторикоксибу, 10 лиг/кг $(p<0,05)$.

мальний, проте виразної дозозалежності не спостерігається. У всіх дозах за фригопротекторним ефектом дарбуфелону мезилат статистично значуще перевершує АСК, а також у дозі 40 мг/ кг перевищує еторикоксиб 10 мг/кг (таблиця). Варто уваги, що саме дарбуфелону мезилат демонструє кращі результати порівняно з основою дарбуфелону та його 2-тіазоліл-заміщеним похідним у зіставлюваних дозах, можливо, у зв'язку з більшою біодоступністю. У більшості досліджень дарбуфелону використовують саме мезилат [16, $21,22]$. Відомо, що активація лейкотрієнових рецепторів ендотелію збільшує проникність судин, що негативно впливає на розвиток ХT, адже вихід плазми з судинного русла за низьких температур призводить до ще більшої травматизації тканин і подальшого розвитку запальної реакції. До того ж це погіршує реологічні властивості крові, що також відіграє значну роль у патогенезі ХT [23]. Результати досліду дають під- ставу вважати, що застосування блокатора ЦОГ-2/5-ЛОГ дозволяє уникнути цих несприятливих явищ, однак це потребує подальших досліджень.

\section{Висновки}

1. Парацетамол не демонструє фригопротекторних властивостей за умов гострого загального охолодження, що означає незначну участь ЦОГ-3 і центральних ланок каскаду арахідонової кислоти в патогенезі холодової травми.

2. Еторикоксиб у дозі 10 мг/кг виявляє найбільшу фригопротекторну активність серед НПЗП - високоселективних інгібіторів ЦОГ-2.

3. Подвійний інгібітор ЦОГ-2/5-ЛОГ дарбуфелону мезилат має потужні фригопротекторні властивості, за якими перевершує високоселективні інгібітори ЦОГ-2. Це демонструє доцільність поглибленого вивчення впливу ліпоксигеназного шляху окиснення арахідонової кислоти на розвиток холодової травми. 
1. Imray C., Grieve A., Dhillon S. Cold damage to the extremities: frostbite and non-freezing cold injuries. Postgraduate medical journal. 2009. № 85. P. 481-488.

2. Капелька І. Г., Штриголь С. Ю. Скринінгове дослідження фригопротекторних властивостей нестероїдних протизапальних препаратів за гострого загального охолодження. Фармакологія та лікарська токсикологія. 2019. Т. 13 (5). С. 338-343.

3. Горелик И. Э. Профилактика некроза при отморожениях конечностей в дореактивном и раннем реактивном периодах: автореф. дис. на соискание учен. степени канд. мед. наук: спец. 14.01.17 «Хирургия», 14.03.03 «Патологическая физиология»; Сибирский гос. мед. университет Росздрава. Кемерово, 2010. 23 с.

4. Wilderness Medical Society Practice Guidelines for the Prevention and Treatment of Frostbite: 2014 Update. S. E. Mclntosh, M. Opacic, L. Freer et al. Wilderness \& Environmental Medicine. 2014. № 2 (22). P. 156-166.

5. Sachs C., Lehnhardt M., Daigeler A. The Triaging and Treatment of Cold-Induced Injuries. Deutsches Arzteblatt International. 2015. № 112. P. 741-748.

6. Коптяева Р. Г. Высокоселективный ингибитор циклооксигеназы-2 при отморожении в условиях острой алкогольной интоксикации. Экология человека. 2005. № 12. С. 54-57.

7. Патент № 2270013, RU, МПК A61K 31/5415 (2006.01), A61P 31/00 (2006.01). Профилактическое и лечебное средство при сочетанной алкогольно-холодовой травме. Коптяева Р. Г., Назаренко Н. А., Леонтьев В Я., Сидоров П. И. Патентообладатель Северный государственный медицинский университет. № 2004107203/15; заявл. 10.03.04; опубл. 20.02.06, Бюл. № 5.

8. Novel Dual Cyclooxegenase and Lipoxygenase Inhibitors Targeting Hyaluronan-CD44v6 Pathway and Inducing Cytotoxicity in Colon Cancer Cells. M. Suniti, G. Shibnath et al. Bioorg Med Chem. 2013. V. 21 (9). P. 2551-2559.

9. Chaoyu Hu, Shutao Ma. Recent development of lipoxygenase inhibitors as anti-inflammatory agents. Med. Chem. Commun. 2018. № 9. P. 212-225.

10. Холодова травма: доклінічне вивчення лікарських препаратів з фригопротекторними властивостями: методичні рекомендації. Є. В. Бондарєв, С. Ю. Штриголь, С. М. Дроговоз та ін. Харків, 2018. 35 с.

11. Бондарєв Є. В., Штриголь С. Ю. Вплив препаратів глюкозаміну та ацетилсаліцилової кислоти на артеріальний тиск і показники ЕКГ за умов експериментальної холодової травми. Фармакологія та лікарська токсикологія. 2017. № 6 (56). С. 31-36.

12. Бондарєв Є. В. Дослідження глюкозаміну гідрохлориду як засобу фригопротекторної дії при поєднаній алкогольно-холодовій травмі. Фармацевтичний часопис. 2012. № 3. С. 140-142.

13. Бондарев E. В. Влияние глюкозамина гидрохлорида и ацетилсалициловой кислоты на показатели углеводного обмена при острой холодовой травме у крыс. Оңтүстік Қазақстан мемлекеттік фармацевтика академия сыныңхабаршысы. 2015. № 1 (70). С. 2-7.

14. Бондарев Е. В., Штрыголь С. Ю. Антигипотермические и антиоксидантные свойства глюкозамина гидрохлорида и ацетилсалициловой кислоты в условиях острой холодовой травмы. Вестник фармации. 2016. № 3 (73). С. 92-97.

15. Pharmacological evaluation and molecular docking of new di-tert-butylphenol compound, LQFM091, a new dual 5-LOX/COX inhibitor. Lino R. C., da Silva DPB et al. Eur J Pharm Sci. 2017. № 106. P. 231-243.

16. Darbufelone, a novel anti-inflammatory drug, induces growth inhibition of lung cancer cells both in vitro and in vivo. X. Ye, W. Zhou et al. Cancer Chemother Pharmacol. 2010. V. 66 (2). P. 277-285.

17. Potential anti-inflammatory effect of LQFM-021 in carrageenan-induced inflammation: The role of nitric oxide. I. F. Florentino, DPB. Silva et al. Nitric Oxide. 2017. № 69. P. 35-44.

18. Guidance for Industry Estimating the Maximum Safe Starting Dose in Initial Clinical Trials for Therapeutics in Adult Healthy Volunteers. URL: https://www.fda.gov/regulatory-information/search-fdaguidance-documents/estimating-maximum-safe-starting-dose-initial-clinical-trials-therapeuticsadult-healthy-volunteers.html.

19. Сергиенко В. И., Бондарева И. Б., Маевский Е. И. Методические рекомендации по статистической обработке результатов доклинических исследований лекарственных средств. Руководство по проведению доклинических исследований лекарственных средств. Часть первая; под ред. А. Н. Миронова. Москва : ГрифиК, 2012. С. 890-940.

20. Fosslien E. Review: Cardiovascular Complications of Non-Steroidal Anti-Inflammatory Drugs. Annals of Clinical \& Laboratory Science. 2005. V. 4 (35). P. 347-385.

21. Slow-Binding Inhibitory of Human Prostaglandin Endoperoxide Synthase-2 with Darbufelone, an Isoform-Selective Antiinflammatory Di-terp-butyl Phenol. A. R. Johnson, M. A. Marletta et al. Biochemistry. 2001. V. 40 (25). P. 7736-745.

22. Synthesis of 4-benzyl-1,3-thiazole derivatives as potential anti-inflammatory agents: An analoguebased drug design approach. R. N. Sharma, F. P. Xavier, K. K. Vasu et al. Journal of Enzyme Inhibition and Medicinal Chemistry. 2009. V. 24 (3). P. 890-897.

23. Peters-Golden M., Henderson W. R. Mechanisms of disease: Leukotrienes. The New England Journal of Medicine. 2007. V. 357 (18). P. 1841-1854. 


\section{І. Г. Капелька, С. Ю. Штриголь, Р. Б. Лесик, А. В. Лозинський, С. В. Хом'як, В. П. Новіков \\ Скринінг низки інгібіторів каскаду арахідонової кислоти на фригопротекторні властивості}

Холодові травми (XT) донедавна були в основному проблемою військових, однак останнім часом збільшується кількість постраждалих серед цивільного населення. Це пов'язано зі зростаючою популярністю активного способу життя та таких його елементів, як спортивний туризм, альпінізм, катання на лижах, і збільшенням кількості безхатченків. Взимку число постраждалих сягає 12000. Більшість хворих потребують стаціонарного лікування, смертність перевищує 10 \%.

За патогенезом XT схожа з запаленням, що розвивається за опіків та ішемічних уражень. Значну роль у патогенезі відіграють продукти метаболізму арахідонової кислоти: тромбоксан, простагландини, лейкотрієни.

Враховуючи роль ейкозаноїдів у механізмі розвитку XT, можна зробити припущення щодо позитивного впливу інгібіторів метаболізму арахідонової кислоти на перебіг цієї патології.

Мета дослідження - порівняти виразність фригопротекторного ефекту низки нестероїдних протизапальних препаратів (НПЗП) з різною селективністю й аналгетика-антипіретика парацетамолу на моделі гострого загального охолодження (ГЗО) у мишей.

Дослідження виконано на білих мишах самцях масою 20-24 г протягом одного дня з 12.00 до 18.00 год. Для моделювання ГЗО мишей вміщували до індивідуальних пластикових кліток об'ємом $500 \mathrm{~cm}^{3}$ без обмеження рухової активності та доступу повітря, розташовували в морозильній камері «Nord Inter-300» з прозорою кришкою за температури $-18{ }^{\circ} \mathrm{C}$. Інтегральним показником фригопротекторної дії обрано час життя тварин.

Використано такі препарати та субстанції: неселективні інгібітори ЦОГ - ацетилсаліцилова кислота (Аспірин, таблетки, «Bayer», Німеччина), диклофенак натрію (Вольтарен, таблетки, «Novartis», Швейцарія); високоселективні інгібітори ЦОГ-2 - целекоксиб (Целебрекс, таблетки, «Pfizer», США), еторикоксиб (Аркоксія, таблетки, «Merck Sharp \& Dohme Idea Inc», США); подвійні інгібітори ЦОГ-2/5-ЛОГ - дарбуфелон, дарбуфелону мезилат, 5-(3,5-ди-трет-бутил-4-гідроксибензиліден)-2(тіазол-2-іліміно)-тіазолідин-4-он (субстанції); інгібітор цОГ-3 - парацетамол (Панадол, таблетки, «Glaxo Smith Kline plc», Ірландія).

Результати дослідження демонструють, що парацетамол не має фригопротекторних властивостей. Еторикоксиб виявляє найбільший фригопротекторний ефект серед класичних НПЗП. Дарбуфелону мезилат демонструє найвищу фригопротекторну активність серед усіх досліджених препаратів. Враховуючи цей факт, можна припустити важливу роль 5-ЛОГ і лейкотрієнів у патогенезі холодової травми.

Ключові слова: холодова травма, фригопротекторная дія, нестероїдні протизапальні препарати, каскад арахідонової кислоти

\section{И. Г. Капелька, С. Ю. Штрыголь, Р. Б. Лесик, А. В. Лозинский, С. В. Хомяк, В. П. Новиков Скрининг ряда ингибиторов каскада арахидоновой кислоты на фригопротекторные свойства}

Холодовые травмы (XT) до недавнего времени были в основном проблемой военных, однако в последнее время увеличивается количество пострадавших среди гражданского населения. Это связано с растущей популярностью активного образа жизни и таких его элементов, как спортивный туризм, альпинизм, катание на лыжах и растущим количеством бездомных. Зимой количество пострадавших достигает 12 000. Большинство больных нуждаются в стационарном лечении, смертность превышает $10 \%$.

По патогенезу ХТ схожа с воспалением, которое развивается при ожогах и ишемических повреждениях. Значительную роль в патогенезе играют продукты метаболизма арахидоновой кислоты: тромбоксан, простагландины, лейкотриены.

Учитывая роль эйкозаноидов в механизме развития ХT, можно предположить наличие положительного влияния ингибиторов каскада арахидоновой кислоты на течение этой патологии.

Цель исследования - сравнить выраженность фригопротекторного эффекта ряда нестероидных противовоспалительных средств (НПВС) с разной селективностью и анальгетика-антипиретика парацетамола на модели общего острого охлаждения (ООО).

Исследование выполнено на белых мышах самцах массой 20-24 г на протяжении одного дня с 12.00 до 18.00. Для моделирования ООО мышей помещали в индивидуальные пластиковые клетки

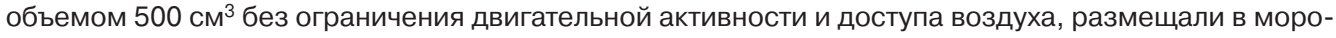
зильной камере «Nord Inter-300» С прозрачной крышкой при температуре $-18{ }^{\circ} \mathrm{C}$. Интегральным показателем фригопротекторного действия выбрано время жизни животных.

Были использованы такие препараты и субстанции: неселективные ингибиторы ЦОГ - ацетилсалициловая кислота (Аспирин, таблетки, «Вауег», Германия), диклофенак натрия (Вольтарен, таблетки, «Novartis», Швейцария); высокоселективные ингибиторы ЦОГ-2 - целекоксиб (Целебрекс, таблетки, «Pfizer», США), эторикоксиб (Аркоксия, таблетки, «Merck Sharp \& Dohme Idea Inc», США); 
двойные ингибиторы ЦОГ-2/5-лОГ - дарбуфелон, дарбуфелона мезилат, 5-(3,5-ди-трет-бутил-4гидроксибензилиден)-2-(тиазол-2-илимино)-тиазолидин-4-он (субстанции); ингибитор ЦОГ-3 парацетамол (Панадол, таблетки, «Glaxo Smith Kline plc», Ирландия).

Результаты исследования демонстрируют, что парацетамол не обладает фригопротекторными свойствами. Эторикоксиб проявляет наибольший фригопротекторный эффект среди всех классических НПВС. Дарбуфелона мезилат демонстрирует максимальную фригопротекорную активность среди всех исследованных препаратов. Учитывая этот факт, можно предположить важную роль 5-лОГ и лейкотриенов в патогенезе ХT.

Ключевые слова: холодовая травма, фригопротекторное действие, нестероидные противовоспалительные средства, каскад арахидоновой кислоты

\section{G. Kapelka, S. Yu. Shtrygol', R. B. Lesyk, A. V. Lozynskyi, S. V. Khomyak, V. P. Novikov$$
\text { The comparative research of arachidonic acid cascade inhibitors for }
$$ frigoprotective activity}

Cold traumas (CT) were once primarily military problems, but are becoming increasingly prevalent among the civilian population. It is associated with a growing interest in outdoor activities such as skiing, hiking, mountaineering and increase in the numbers of homeless. Occurrence of CT grows up in winter, when number of injured reaches more then 12000 people. Most of the injured need hospital treatment, mortality is excess $10 \%$ of cases.

Research as to the pathophysiology of frostbite has revealed notable similarities with the inflammatory processes seen in burn injuries and ischaemia/reperfusion injury. Evidence for the role of tromboxanes and prostaglandins has resulted in a more active approach to the medical treatment of frostbite.

Considering the role of eicosanoids in the development of CT we can assume positive influence of arachidonic acid cascade inhibitors for such pathology.

The aim of the work is to compare the power of frigoprotective effect of NSAIDs with different selectivity and paracetamol using the model of acute general cooling.

The experiment was carried out using healthy white male mice weighing 20-24 g during single day from 12.00 till 18.00 . Mice were put into individual $500 \mathrm{~cm}^{3}$ plastic cages with free access to air and without movement restriction. Cages were situated inside the freezer «Nord Inter-300» with transparent top and at a temperature of $-18^{\circ} \mathrm{C}$. An integral index of frigoprotective effect was chosen the duration of life.

Drugs and substances that were used in the experiment: nonselective inhibitors of COX - acetylsalicylic acid (Aspirin, tablets, «Bayer», Germany), diclofenac sodium (Voltaren, tablets, «Novartis», Switzerland); highly selective inhibitor of COX-2 - celecoxib (Celebrex, tablets, «Pfizer», USA), etoricoxib (Arcoxia, tablets, «Merck Sharp \& Dohme Idea Inc», USA); inhibitor of COX-3: paracetamol (Panadol, tablets, "Glaxo Smith Kline plc", Ireland); double inhibitor of COX-2/5-LOX - darbufelone, darbufelone mesylate, 5-(3,5-di-tret-butyl-4-hydroxybenziliden)-2-(thiazol-2-ilimino)-thiazolidin-4-on (substances).

The results of the present study show that paracetamol doesn't demonstrate frigoprotective activity. Etoricoxib render the highest frigoprotective effect among traditional NSAIDs. Darbufelone mesylate shows the highest frigoprotective activity among all used inhibitors of arachidonic acid cascade. Considering that we can suppose important role of 5-LOX and leukotrienes in pathogenesis of cold trauma.

Key words: cold trauma, frigoprotective action, NSAIDs, arachidonic acid cascade

Прийнята до друку: 22 квітня 2020 р.

Контактна особа: Капелька Ігор Геннадійович, аспірант, кафедра фармакології, Національний фармацевтичний університет, буд. 12, вул. Куликівська, м. Харків, 61003. Електронна пошта: kig1997@gmail.com 